\title{
Correction: Nuclear receptor HNF4a performs a tumor suppressor function in prostate cancer via its induction of p21-driven cellular senescence
}

\author{
Zhu Wang $\cdot$ Youjia Li $\cdot$ Dinglan Wu $\cdot$ Shan Yu $\cdot$ Yuliang Wang $\cdot$ Franky Leung Chan
}

Published online: 20 August 2020

(c) The Author(s) 2020. This article is published with open access

Correction to: Oncogene 39:1572-1589 (2020)

https://doi.org/10.1038/s41388-019-1080-3;

Article published online 6 November 2019

The original version of this Article contained an error in the spelling of the author Chan FL, which was incorrectly given as leung Chan F. This has now been corrected in both the PDF and HTML versions of the Article.
Open Access This article is licensed under a Creative Commons Attribution 4.0 International License, which permits use, sharing, adaptation, distribution and reproduction in any medium or format, as long as you give appropriate credit to the original author(s) and the source, provide a link to the Creative Commons license, and indicate if changes were made. The images or other third party material in this article are included in the article's Creative Commons license, unless indicated otherwise in a credit line to the material. If material is not included in the article's Creative Commons license and your intended use is not permitted by statutory regulation or exceeds the permitted use, you will need to obtain permission directly from the copyright holder. To view a copy of this license, visit http://creativecommons. org/licenses/by/4.0/. 